PERM JOURNAL OF PETROLEUM AND MINING ENGINEERING

ВЕСТНИК ПНИПУ. ГЕОЛОГИЯ. НЕФТЕГАЗОВОЕ И ГОРНОЕ ДЕЛО

ISSN 2224-9923

Volume / Tом 17 №2 2018

http://vestnik:pstu.ru/geo/

УДК 622.276.03:622.691.4

Article / Статья

(C) PNRPU / ПНИПУ, 2018

\title{
ECOLOGICAL, GEOCRYOLOGICAL AND GEOTECHNICAL CONDITIONS OF THE GAS TRANSPORTATION SYSTEM "FORCE OF SIBERIA"
}

Mikhail N. Zheleznyak, Sergey I. Serikov, Mark M. Shatz

Melnikov Permafrost Institute of the Siberian Branch of the Russian Academy of Sciences

(36 Merzlotnaya st., Yakutsk, 677010, Russian Federation)

\section{ЭКОЛОГО-ГЕОКРИОЛОГИЧЕСКИЕ И ГЕОТЕХНИЧЕСКИЕ УСЛОВИЯ ГАЗОТРАНСПОРТНОЙ СИСТЕМЫ «СИЛА СИБИРИ»}

\section{М.Н. Железняк, С.И. Сериков, М.М. Шац}

Институт мерзлотоведения имени П.И. Мельникова Сибирского отделения Российской академии наук (677010, Россия, г. Якутск, ул. Мерзлотная, 36)

Received / Получена: 24.03.2018. Accepted / Принята: 09.06.2018. Published / Опубликована: 29.06.2018

Key words:

selection of pipeline route, specific engineering and geological conditions, pipe laying and construction of system, advantages and problems of chosen route.

\begin{abstract}
The subject of the paper is the response of the natural environment to various impacts associated with the oil and gas industry. The paper is devoted to the analysis of the current state of implementation of the project of development of the gas transportation system "Power of Siberia" in East and Southeast Siberia. The purpose of the study is to show the problems that arise at various stages of creating the object. That includes choosing the apropriate pipeline route and method of pipe laying.

The project of gas transoptation system (GTS) "Power of Siberia" in East Siberia is being successfully implemented recently. The stages of exploration and design are completed, pipe is being layed. After successful research and design, one of the most important stages (pipe laying and system building in general) has started. Studying the seasonal and permafrost rocks is a very special direction in the general integrated system of engineering and geological knowledge. It is important to consider both studied parameters such as composition, structure, properties of rocks, and features of aggregate states of the object of research. Negative temperatures cause fundamental differences in the composition of rocks with the development of diverse underground ice, sometimes constituting up to $90 \%$ of the thickness, and other characteristics.

The main results of ecological and geocryological research recently performed by Melnikov Permafrost Institute of the Siberian Branch of the Russian Academy of Sciences, which have revealed the main difficulties of the project and show the ways of their solution, are given. Advantages and features of the selected route in the specific engineering and geological conditions are described. The need for underground method of pipe laying is confirmed.

It is concluded that complex and diverse natural conditions of the route of the GTS determine a number of specific problems at the stages of construction and operation within areas with permafrost soils and dangerous geocryological and engineering-geocryological processes. It is possible to avoid them only while studying the most difficult areas.

Recommendations on the structure of department of engineering and geocryological monitoring are given.
\end{abstract}

Предметом статьи является реакция природной среды на различные воздействия, связанные с нефтегазовой отраслью. Проанализировано современное состояние реализации проекта создания газотранспортной системы «Сила Сибири» в Восточной и Юго-Восточной Сибири. Цель исследования - показать проблемы, возникающие на различных стадиях создания объекта. К ним отнесены выбор варианта трассы трубопровода, способа прокладки трубы.

Проект газотранспортной системы (ГТС) «Сила Сибири» в Восточной Сибири в последнее время успешно реализуется. Завершены стадии изысканий и проектирования, в разгаре прокладка трубы. После успешных изысканий и проектирования начат один из наиболее ответственных этапов - прокладка трубы и строительство системы в целом. В общей комплексной системе инженерно-геологических знаний совершенно особым направлением является изучение сезонно- и многолетне-мерзлых пород. И дело не только в изучаемых параметрах составе, строении и свойствах горных пород, но и в особенностях агрегатных состояний объекта исследований. Отрицательные температуры обусловливают принципиальные отличия в составе горных пород с развитием разнообразных подземных льдов, иногда составляющих до 90 \% толщи, и иных характеристик.

Приведены основные результаты эколого-геокриологических исследований Института мерзлотоведения СО РАН последних лет, позволившие выявить главные сложности проекта и показать пути их решения. Показаны достоинства и описаны проблемы выбранного варианта трассы в конкретных инженерно-геологических условиях, подтверждена целесообразность применения подземного способа прокладки труб. Сделаны выводы, что сложные и разнообразные природные условия трассы ГТС обусловливают на стадиях строительства и эксплуатации в пределах участков с многолетне-мерзлыми грунтами и опасными геокриологическими и инженерно-геокриологическими процессами ряд специфических проблем. Избежать их можно лишь при условии доизучения наиболее сложных участков.

Даны рекомендации по структуре ведомственного инженерно-геокриологического мониторинга.

Mikhail N. Zheleznyak (Author ID in Scopus: 22959266400) - Doctor of Geology and Mineralogy, Professor, Director (tel.: +007 914 226 93 47, e-mail: fe@mpi.ysn.ru). Sergey I. Serikov - Scientific fellow (tel.: +007 91429472 63, e-mail: grampus@mpi.ysn.ru).

Mark M. Shatz - PhD in Geography, Leading Research Fellow (tel.: +007 921102 05 76, e-mail: mmshatz@mail.ru). The contact person for correspondence.

Железняк Михаил Николаевич - доктор геолого-минералогических наук, профессор, директор (тел.: +007 91422693 47, e-mail: fe@mpi.ysn.ru) Сериков Сергей Иванович - научный сотрудник (тел.: +007 91429472 63, e-mail: grampus@mpi.ysn.ru).

Шац Марк Михайлович - кандидат географических наук, ведущий научный сотрудник (тел.: +007 921102 05 76, e-mail: mmshatz@mail.ru). Контактное лицо для переписки. 


\section{Introduction}

The project of gas transmission system (GTS) "Power of Siberia" has been successfully implemented in Eastern Siberia recently. Exploration and design stages are completed. Pipe laying is in the middle stage. Complex natural (including engineering and geological conditions of the route), geotechnical and geoecological characteristics of the pipeline as well as a number of following points of different departmental affiliations have been discussed recently [1-32]. The pipe laying process at of the beginning of 2017 is considered in $[33,34,36]$. A particularly important task of the current stage is to obtain operational information on the state of the natural environment along the GTS route, namely, reaction of its most dynamic components, including permafrost rocks, to technogenic impacts. In case the materials mentioed above are not given or insufficient it usually leads to uncertainty when selecting the nature management strategy. The uncertainty is associated with inability to develop a plan for specific environmental and compensation measures. Their implementation allows to significantly reducing the damage from development.

This position can be confirmed by the following unfortunate example. In the middle of last century a grandiose construction of the largest complex "Atommash" for the production of equipment for the nuclear industry was launched in the Volga region. Substandard research and design led to serious mistakes.

The volume of materials on geotechnical properties of rocks, sufficient for reliable predictions was not received. As a result, the complex was placed on subsidence grounds. Moreover, when designing for the sake of economy, it was decided to cut several meters of the length of piles in grounds of huge and many hundreds of meters long hulls.

As a result of a significant rise in a groundwater level, fed by unusually large amounts of precipitation, unacceptable subsidence of rocks occurred in foundations of many buildings, resulting in violations of their stability even before the construction was completed. There were no technical solutions for correcting the situation at the time. It was not possible to develop new ones. The construction had to be mothballed. Thus, due to criminal negligence and underestimation of the value of engineering and geological support for construction, colossal budgetary losses were committed.

In a general complex system of engineeringgeological knowledge study of seasonal and permafrost rocks is a very special area. That is not just a problem of the parameters studied such as composition, structure and properties of rocks. Features of the aggregate states of a research object should be considered as well. The temperatures below zero can cause fundamental differences in composition of rocks with development of a variety of underground ice up to $90 \%$ in thickness sometimes and other characteristics. In development of the northern territories, when layers with specific properties are fundamentally different from the properties of not permafrost rocks these properties are of particular importance.

That is not possible to develop modern cryolithozone, use its resources, as well as living of the urban and rural population are impossible without a systematic assessment of the cumulative impact on it of both projected and existing industrial facilities. Their interconnection combined with an assessment of the consequences of socio-economic, ecological, historical-cultural and medical-biological processes is a complex task that requires the deep systematic approach and has a fundamental social and regional importance. The ecological-geocryological component has recently become the most relevant in the general system of engineering-geological knowledge.

\section{Ecological, geocryological conditions and challenges of the GTS route}

It was mentioned above that one of the serious obstacles to implementation of a project is the lack of operational information on the state of the natural environment along the route. In this regard, results of comprehensive studies of staff of the Melnikov Permafrost Institute of the Siberian Branch of the Russian Academy of Sciences obtained recently became interesting in particular. 
In general, the relief that cause the variety of natural conditions of the route causing the diversity of the GTS is complex. That includes high mountain ranges, plateaus, uplands and lowlands, divided by river valleys [13, 19, 20, 32]. The highest mountains are located in the southern and south-eastern parts of the territory, where the prevailing elevation above the sea level is from 800 to $1500 \mathrm{~m}$. The main elements are elongated in the sublatitudinal or north-eastern direction. The area of the Aldan plateau includes large MesozoicCenozoic morphostructures of the latitudinal direction such as the Chulman basin and CentralAldan low-lying arch. The morphostructure of the Chulman basin, made of sandy-argillaceous deposits of the Jurassic and Lower Cretaceous, is characterized by a plateau type relief. The relief of the Chulman plateau is characterized by the presence of wide flat or gently sloping watersheds with rather steep stepped slopes. The heights of the watersheds are $950-1050 \mathrm{~m}$ and increase to the south up to $1200 \mathrm{~m}$.

The pipeline route crosses the Stanovoy Range at the junction of the Republic of Sakha (within the Neryungri District) and the Amur Region within the Tynda District. Stanovoy ridge consists of two and in some places three parallel chains, not always clearly expressed orographically. Absolute altitudes along the route reach $1000-1100 \mathrm{~m}$.

Geocryological and engineering-geocryological conditions along the GTS route "Power of Siberia" are extremely various and complex $[1,9,11,13$, $14-16,21-28,31]$. In general, the permafrost covers about a third of the route, recorded areas with all types of their spatial distribution - from continuous and intermittent to island and sporadic. In terms of a rock section, the strata is represented by both monotonous and polygenic structure, while the latter are the most dangerous for pipelines laid underground causing additional stresses in pipes such as frozen soil systems.

The temperature of rocks at the base of a layer of its annual fluctuations, usually 10-12 m, varies widely, depending on the soil cover, composition, structure and properties of the rocks themselves. The lowest temperatures are typical for low areas of development of waterlogged, sometimes swampy soils and the most elevated mountain areas, reaching there $-6,5^{\circ} \mathrm{C}[15,16]$. The Fig. 1 shows the temporal dynamics of the temperature of rocks on one of their sections of the route.

Against the background of such a variety of natural conditions engineering-geological cryogenic processes are complex, especially dangerous for while completion $[2-8,12,17,18,29,32]$. They are characterized by a Variety of forms and confinement to certain elements of the relief (bottoms and lower parts of the slopes of the valleys). They are more limited they are developed on the watersheds.

Frost-breaking fracturing of rocks, cryogenic weathering, glare ice formation and soil priming are spread widely, when thermokarst and solifluction are not so common [22, 32].

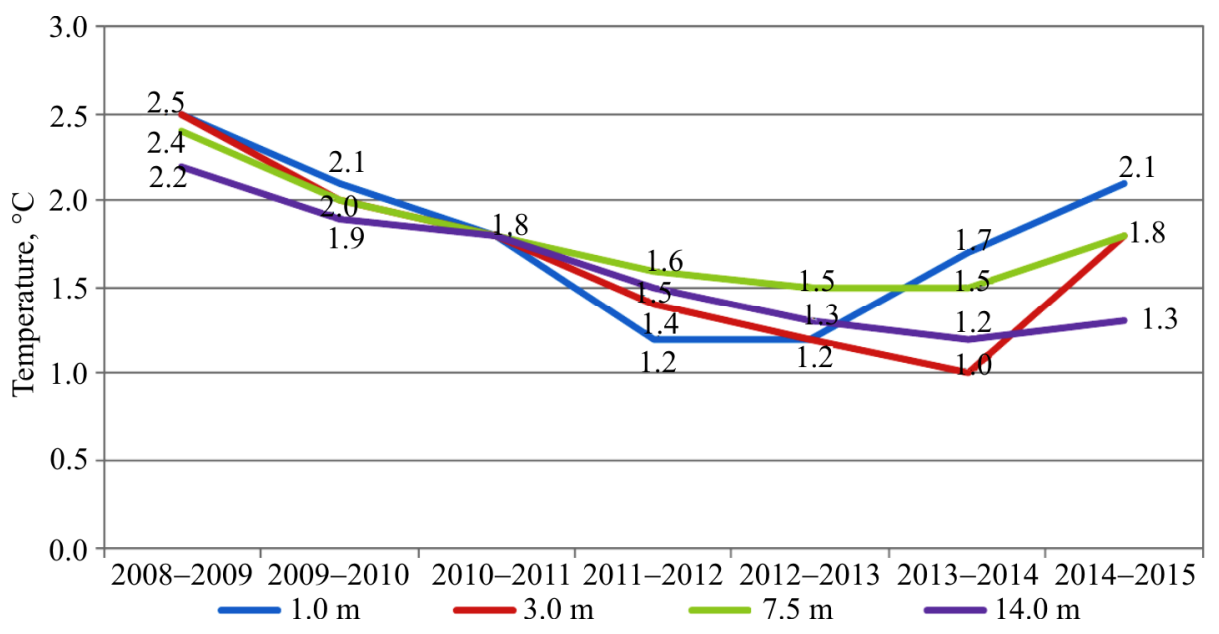

Fig. 1. Dynamics of rock temperature in the section "AYaN" for the period 2008-2015 
Frost cracking causes the loss of solidity and strength of rock massifs, formation of processes and phenomena unfavorable for construction and operation of engineering structures, such as fractures (Fig. 2) and stone seas (kurums) (Fig. 3).

At the foot of small local uplifts, deposits of underground ice, numerous forms of coarse and small hilly relief (Fig. 4) are formed, and slope processes.

The freezing cracks in the surface sediments and polygonal relief associated with them are most clearly expressed on the surface of low accumulated terraces, in the lower parts of the gentle slopes, the upper reaches of the rivers Iengra, Timpton, Ulahan-Legliger and others.

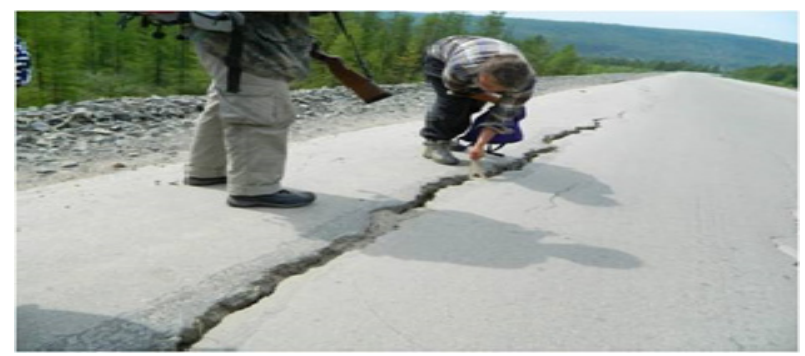

Fig. 2. Fracrures on the roadway with a hard surface at the mouth of the river. The Great Key. Photo by S.I. Serikova, 2015

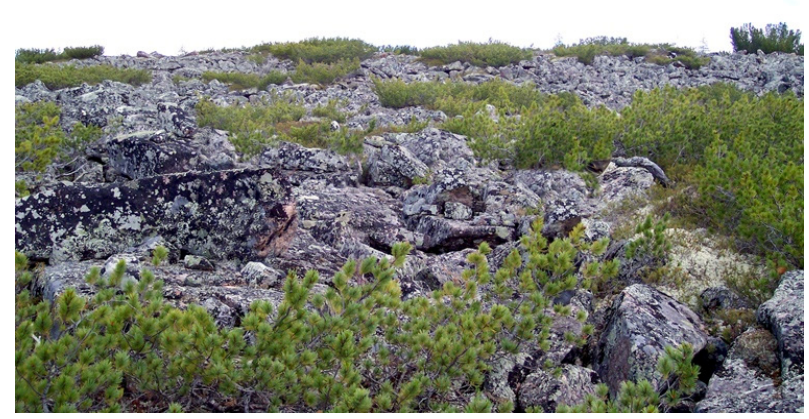

Fig. 3. Stone sea on the slope of the interfluve of rivers Taiga, Goltsovy, composed of large-grained material. Photo by S.I. Serikova, 2015

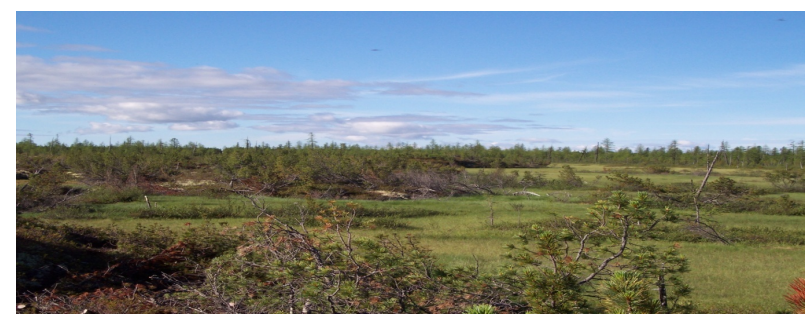

Fig. 4. Littered bumpy-sapstone section of the GTS route. Photo I.V. Dorofeeva, 2012
Here the average sizes of the polygons reach $10 \times 10 \mathrm{~m}$, which indicates low average annual rock temperatures. The maximum width of cracks on the terraces above the floodplain reaches $0.2-0.5 \mathrm{~m}$ with a length of $20-40 \mathrm{~m}$ and a visible depth of 2-3 m. At the watersheds and in the upper reaches of the valleys there are peat bogs, which are peat blocks measuring $30 \times 50 \mathrm{~m}$, separated by a polygonal network of fractures. The blocks from the surface are composed of peat up to 2-3 m thick, underlain by heavy loams containing ice veins up to $3 \mathrm{~m}$ thick and up to $2 \mathrm{~m}$ wide. The maximum width of veins is fixed on the contact of peat and loam. Repeated veins of ice are found in the valleys of rivers Orochenka, Vasilyevka, Nikolkin klyuch, and others. Fracturing in ductile (sandy loamy) rocks, not accompanied by the filling of cracks with water and formation of veins of ice is the most characteristic for the territory under consideration [32]. This kind of cracking is expressed in formation of a special type of frozen micro relief - bumpy mare with a polygon size from $2 \times 1.5$ to $3 \times 5 \mathrm{~m}$, less often up to $5 \times 10 \mathrm{~m}$. The width of fractures varies from $5-15 \mathrm{~cm}$ to $0.5 \mathrm{~m}$ and more at a depth of 0.2 to $0.7 \mathrm{~m}$. On the gently sloping $\left(1-3^{\circ}\right)$ sections of the slopes, the fracture of the surface soils is clear and polygons have large side dimensions of tens of meters. The polygons are smaller on steeper slopes (3-6 $\left.{ }^{\circ}\right)$.

In addition to the polygonal relief structural forms of the microrelief in the form of stone polygons, especially widely developed in the central part of the Aldan plateau, stone rings and bands on the Chulman plateau [32]. Usually, stone polygons reach a diameter of 2-3 $\mathrm{m}$ on the rocks of carbonate and terrigenous formations and $3-10 \mathrm{~m}$ on the rocks of the magmatic group of formations. Polygon borders are often represented by fragments of rock formations from 0.1 to 1 meter or more in size, bearing traces of frost sorting and bulging, and rocks within polygons or rings are of smaller size or generally represented by fine earth. Polygons have a shape close to the right one and on steeper slopes (up to $10^{\circ}$ ) they often take the form of stone bands. Mountain terraces are the example of polygonal relief within the development of rock on flat watersheds [29]. 
The shallow occurrence along the permafrost route and associated waters of seasonal thawing layer contributes to broad development of soil preparation processes that are very unfavorable for engineering development. There are two types of developmental of high spot such as annual and perennial. Permafrost mounds are developed the most widely in the swampy upper reaches of river valleys and in areas composed of loamy, decayed sediments [32]. In addition, permafrost mounds are noted in swampy and mossy areas of terraces and watersheds, and especially within the weakly dissected part of the Aldan plateau.

Seasonal (annual) mounds in 0.5-0.8 height and $1-2 \mathrm{~m}$ in diameter are mainly confined to areas of excessive moistening - rear seams of the terraces, channel sections of streams and rivers, watershed saddles, marshy slopes [32]. Numerous lenses or ice layers are observed in cores of hillocks. Such mounds form a specific microrelief of bottoms of most of the watercourses of basins of the rivers of the Small and Large Nimnyr, UlahanLehliger and others that is characterised by widespread development of a specific "drunk forest".

Perennial mounds such as hydrolyser-colites occur more locally, reach a height of $5 \mathrm{~m}$ and diameter of the base of 15-25 m. They are usually confined to places of unloading of fissured veins and other groundwater (basins of the rivers Vasilyevka, Kerak etc.) [32]. The largest mound on the floodplain of the river Gorblyakh is recorded within the watered sedge-sphagnum marsh. The shape of the hill is oval, the height is 4-5 $\mathrm{m}$ and length of the base is $15-20 \mathrm{~m}$.

Patches-medallions, stone polygons and others are widely spread [32] which is another example of blow-ups and assortment. The process of irregular blow-up, associated with freezing of water in a closed volume, is the most geotechnically dangerous one and can lead to buckling of underground pipelines due to the inflow of moisture to the freezing front.

There are deposits of underground ice of two generations such as re-veined and injected observed at the route of the GTS laying. In the northern part of the route, re-veined ice is confined to terraces of large floodplains and fragments of the lake-alluvial plain in the areas of the middle Lena, where thermokarst lakes are found in their development areas. Certain coming outs of reveined ice for the route of study are known in the valleys of some rivers of the Aldanskiy Shield in southern Yakutia and even in the north of the Amur Region [1-3].

Surface deposits have small ice content with a shallow bedding of the bedrock on most of the GTS route. Therefore, small thermokarst shapes of destructive orientation dominate there. They are represented by hollows and funnels that reach $0.5-2.0 \mathrm{~m}$ in diameter and $0.5 \mathrm{~m}$ in depth and developed in Precambrian metamorphic and magmatic formations on flat regions of the distribution of rocks. They are caused mainly by an increase in depth of seasonal thawing of highly icy deluvium loams during evolution of a microrelief and vegetation cover. Thermokarst lakes of $300 \mathrm{~m}$ in diameter (Kabakta river basin etc.) are presented less often [1]. To the south of the village Chulman thermokarst lakes are more common in the valley of the river Gorbylyakh, on the first terrace in particular. The lakes is rounded or oval-drawn, the bottom is flat. Diameter of small ones is in the range from 5.0 to $10.0 \mathrm{~m}$, large ones - up to 200-300 m. According to [3], features of the geographical distribution of permafrost in South Yakutia suggest that there is no thermokarst processes only on slopes and watersheds of the Lena-Aldanskiy and Chulman Plateaus.

Another structure of thermokarst is found within the sharply devided planar massifs such as a mound-hollow relief. It is usually formed in bottoms of narrow river valleys, filled with fluvioglacial material, which has a great ice content and erosion-thermokarst origin. Rounded mounds with a diameter of $15-50 \mathrm{~m}$ and height of up to $2.0 \mathrm{~m}$, separated by strips of articulating hollow, genetically represent fragments of the first or second above-flood terraces. Areas of alluvial plains (Tokarikano-Iengarsaya and others) and gently undulating areas of plateaus (Chulmanskiy, Nimnyro-Ylymakhskiy) are special in terms of development of thermokarst. The specificity of thermokarst relief structure here is determined by the high ice content of the cover deposits and conditions for discharge of surface waters [32]. 
Thawing of underground ice in combination with frost puffing, frost busting, solifluction, erosion and flat flushing create here original complexes of cryogenic relief forms that are not found in other parts of the central part of South Yakutia $[2,3]$.

It should be especially noted that the territory, which is affected by the construction and operation of the main gas pipeline "Power of Siberia", belongs to one of the most dangerous regions in our country [2-8, 10, 17]. In accordance with the materials available, only 12 sections of soil grounding and three with ice were recorded within the section of the Chayanda-Lensk route. There were 3 sites with ice and 273 sites of seasonal or long-term swelling in Lensk-Skovorodino section. Ice is quite often formed accompanied by the development of seasonal and perennial mounds as well as thermokarst processes in deposits of injected and re-veined ice. Therefore, all those sites should be considered in terms of engineering development as potentially hazardous ice formation.

Results of interpretation of spatial patterns of the development of ice sheets along the route of the GTS testify to their wide distribution from the central part of southern Yakutia to south of the Amur Region. In such conditions there is a possibility of an increase in ice formation at the intersections with the route.

Experience of the previous engineering development (construction and operation of the federal motorway Lena, often referred to as AYaM, the Amur-Yakutsk railway and BaikalAmur railway, the East Siberia-Pacific Ocean oil pipeline) $[2,18,33,34,35]$, the areas of ice formation within the mountain sections of the route should be concidered as the most geotechnically problematic. The impact of the pipeline itself and other associated engineering structures on the ground causes a change in the thermal regime and properties there. Permafrost karst has the same complexity and integrity. There are data on multiplicity and activity of karst craters in the areas of permafrost development within the LenaAldan karst plateaus located north of the Siberian Power Plant route, active karst craters directly in the Priyuyskaya part of the Chayandinskoye oil and gas gas condensate field (ChOGCF), at the
Yakokit-Seligdarskoe interfluve, transition of the Aldan and Chulman plateau [20,30]. Such sites are particularly dangerous in terms of geotechnical reliability and require close attention from the period of reconnaissance work to stages of construction and operation. That areas usually become the basis for development of other processes such as active tectonic faults, weakened zones of crushing of bedrock, ice formation etc.

The ChOGCF is a GTS source base, which represnts a slightly hilly plain in orographic scence [20]. It was discovered in 1989 and includes two smaller deposits such as Ozernoe and NizhneHamakinskoye. According to the oil geological zoning, the area belongs to the NepaBotuobinskaya oil and gas region which is the richest in the known reserves of hydrocarbons and forecast resources of the part of the LenoTungusskaya oil and gas province, where 13 oil and gas fields are explored including three large and one unique.

Basal deposits of the Riphean-Vendian-Lower Cambrian terrigenous-carbonate complex are the main oil and gas bearing strata. The field is confined to a large non-anticlinal trap in the northeastern part of the Nepa arch and associated with zones of wedging of Vendian sandstones.

The main formations are as follows: botuobinskiy (corresponds to the lower sub-series of the Byukskaya suite), Hamakinskiy (correspond to the upper sub-series of the Parshinskaya series). The formations are composed of lenticular bodies of predominantly medium and fine-grained wellsorted sandstones with quartz and sulfatecarbonate cement. Thickness of the bodies reaches $20 \mathrm{~m}$. All reservoirs are layer-type, lithologically and tectonically shielded. Depth of the deposit is 1450-1850 m. Disruptive violations divide the field into two blocks such as the northern and southern ones. There are three types of gas: methane (86\%), low-carbon, nitrogen gas (up to $8 \%$ ) and lowcondensate gas. The gas deposits contain oil rims. Oil is heavy, tarry, sulfurous and paraffinic.

\section{Current state of the project}

Currently, the main focus is on two main aspects of project implementation. First of all, it is a set of challenges related directly to construction 
of the pipeline. Secondly, continuous development of the resource base of the GTS - Chayandinskoe OGCF. The history of the initial stages of project implementation was covered earlier [34].

On 21 May 2014 Gazprom and CNPC signed a 30-year contract for purchase and sale of Russian gas along the eastern route via the "Power of Siberia" gas pipeline. The document assumes the supply of 38 billion cubic meters of gas per year to China. In 2015 Gazprom and CNPC signed a memorandum of understanding on the project of pipeline supplies of natural gas to China from the Russian Far East. In 2016 the companies signed a memorandum on gas storage and power generation in China and memorandum on study of the possibility of cooperation in the field of gas engine fuel.

On 4 July 2017 Gazprom and CNPC signed an additional agreement to the contract of sale of natural gas along the eastern route. According to the document, gas supplies to the People's Republic of China should begin on 20 December 2019 [35].

Gazprom has already built 1 thousand $120 \mathrm{~km}$ of the "Power of Siberia" pipeline, 1 thousand $348 \mathrm{~km}$ welded into a line, the chairman of the board of Gazprom PJSC A. Miller told journalists.

At the end of 2017 A. Miller confirmed that the supply of "blue fuel" to China will begin exactly on time. According to the agreement with the Chinese corporation CNPC, Russia will supply 38 billion cubic meters per year for 30 years with a total contract amount of $\$ 400$ billion [36]. In addition to the pipeline, construction of a huge Amurskiy gas refining plant, which will become the largest in Russia, will be an important link in the chain of gas supplies to China and one of the world's largest natural gas refining enterprises. The design capacity of the plant will reach 49 billion cubic meters of gas per year. The structure of the plant will also include the world's largest production of helium - up to 60 million $\mathrm{m}^{3}$ a year. The plant will receive a multicomponent gas from Yakutsk and Irkutsk gas production centers, which Gazprom creates within the framework of the eastern gas program. Such valuable for gaschemical and other industries gases as ethane, propane, butane, pentane-hexane fraction and helium will be released at the gas refining plant.
The Chayandinskoe deposit has a complex geological structure and special thermobaric reservoir conditions. Therefore, Gazprom uses the most advanced technical achievements for its development. Technologies that need a small number of employees are used in rough natural and climate conditions of Yakutia, which presuppose control over the operation of equipment and complex management of objects in automatic mode. Such the approach contributes to optimization of the number of staff, reduction of transport costs in the transport of people, refusal of excessive construction of infrastructure associated with the stay of workers in facilities.

The field has a large area, therefore, in order to reduce costs for construction of power lines in remote bushes of gas wells, it is planned to use autonomous sources of energy supply based on renewable energy sources.

The Chayandinskoye field will be the first one in Russia at which the technology of membrane extraction of helium from natural gas directly into the field will be implemented [34]. The technology allows sending the amount of helium that will be in demand in market to the pipeline. In the last development period, eighteen exploratory wells were drilled in the field, more than $4,000 \mathrm{~km}^{2}$ were explored with 3D-siesmic. That will help to assess in detail the majority of categories of reserves.

An assessment of the degree of environmental damage risk during the project is another serious problem [34, 37]. There are many approaches to this assessment [37-48]. Experts have to choose the most reliable and objective as applied to local conditions.

\section{Conclusion}

According to results of the studies conducted, the most complex areas where systematic monitoring studies are needed related to the threat of thermokarst in deposits of underground ice and ice beds belong to the area from the river Biryuk to Olekma. The section between the Chayandinskoye field and compressor station (CS) 4 "Nimnyrskaya" and small section between the "Nimnyrskaya" CS and Nagornaya compressor station is under the karst danger. There is an ice 
danger on the section of the route from the river Nyuya up to the river Maly Inym.

Particular attention should be given to the permafrost karst developed on the Lena-Aldanskiy and Prilensky Plateaus. There are places with active karst funnels even within the Chayandinskoe OGCF. That can lead to serious negative consequences and failures of technogenic systems in case of anthropogenic violation during construction and exploitation of the GTS. It is noted that in case of several effects exogenous processes on the same section of the pipeline route, even if they are at different times, the damage to geosystems increases and geotechnical risks of operational reliability are exacerbated. Complex and diverse natural conditions of the route of the
GTS determine a number of specific problems at the stages of construction and operation within the areas with perennial-frozen soils and dangerous geocryological and engineering-geocryological processes. They can be avoided only if the most difficult sites are studied:

- nature of permafrost distribution;

- geothermal conditions with wells;

- specific data on spatial development of cryogenic processes, their dynamics, trends and intensity;

- thermophysical characteristics of the ground cover required for prediction of thermal engineering calculations.

That will reduce the effect of technological hazards and cost of their optimization.

\section{References}

1. Alekseev V.R. Zakonomernosti rasprostraneniia mnogoletnemerzlykh gornykh porod na iugo-vostoke Sibirskoi platformy [The laws of the proliferation of permafrost rocks in the southeast of the Siberian platform]. Geokriologicheskie usloviia Zabaikalia $i$ Pribaikalia, Moscow, Nauka, 1967, pp.117-123.

2. Alekseev V.R. Indikatsionnoe znachenie geobotanicheskikh kart pri izuchenii merzlykh gornykh porod [Indicative value of geobotanical maps in the study of frozen rocks]. Doklady Instituta geografii Sibiri i Dalnego Vostoka, 1968, iss.17, pp.20-26.

3. Alekseev V.R. Usloviia formirovaniia i rasprostranenie naledei na iuge Iakutii [Terms of formation and distribution of rains in the south of Yakutia]. Naledi Sibiri. Moscow, Nauka, 1969, pp.31-41.

4. Alekseev V.R. Naledi kak faktor dolinnogo morfolitogeneza [Glaze as a factor of valine morpholithogenesis]. Regionalnaia geomorfologiia Sibiri, Irkutsk, 1973, pp.99-134.

5. Alekseev V.R. Naledi Leno-Amurskogo mezhdurechia [Glaze of the Leno-Amur Intercontinental]. Sibirskii geograficheskii sbornik. Novosibirsk, Nauka, 1975, pp.46-127.

6. Alekseev V.R. Printsipy i metody otsenki nalednoi opasnosti [Principles and methods for assessing the extreme danger]. Geografiia $i$ prirodnye resursy, 1980, no.2, pp.117-122.

7. Alekseev V.R. Problemy kartografirovaniia nalednykh iavlenii [Problems of flying mapping]. Materialy gliatsiologicheskikh issledovanii, Moscow, 1988, iss.61, pp.140-142.

8. Alekseev V.R. Landshaftnaia indikatsiia nalednykh iavlenii [Landscape display of flying phenomena]. Novosibirsk, Nauka, 2005, 364 p.
9. Baikalo-Amurskaia zheleznodorozhnaia magistral [Baikal-Amur Railway]. Geokriologicheskaia karta. Masshtab 1: 25000 000. Moscow, GUGK, 1979, 21.

10. Balobaev V.T. O nekotorykh osobennostiakh vykhoda na poverkhnost nalednykh istochnikov v iuzhnoi Iakutii [Some features of the exit to the surface of the ice springs in southern Yakutia]. Naledi Sibiri, Moscow, Nauka, 206 p.

11. Belokrylov I.D., Efimov A.I. Mnogoletnemerzlye porody zony zhelezorudnykh i ugolnykh mestorozhdenii iuzhnoi Iakutii [Perennial frozen species of the zone of iron ore and coal deposits of southern Yakutia]. Moscow, Izdatelstvo AN SSSR, 1960, 75 p.

12. Vasilchuk Iu.K., Vasilchuk A.K., Budantseva N.A., Chizhova Iu.N. Vypuklye bugry pucheniia mnogoletnemerzlykh torfianykh massivov [Convex bumps of perennial frosty peat massifs]. Moscow, Izdatelstvo Moskovskogo gosudarstvennogo universiteta, 2008, 560 p.

13. Geokriologiia SSSR. Sredniaia Sibir [Geocryology of the USSR. Middle Siberia]. Moscow, Izdatelstvo Moskovskogo gosudarstvennogo universiteta, $383 \mathrm{p}$.

14. Zhelezniak M.N. Temperaturnoe pole gornykh porod perekhodnoi zony Prilenskogo plato i OlekmoCharskogo ploskogoria [The temperature field of the rocks of the transition zone of the Prilensky Plateau and the Olekmo-Charsky Plateau]. Regionalnye inzhenernye $i$ geokriologicheskie issledovaniia, Iakutsk, IM SO AN SSSR, 1985, 117-127 p.

15. Zhelezniak M.N. Geotermicheskie usloviia formirovaniia i sushchestvovaniia kriolitozony v zapadnoi chasti Aldanskoi anteklizy [Geothermal conditions for the formation and existence of the cryoliton in the western part of the Aldan anteclusis]. Iakutsk, Izdatelstvo SO RAN, 1998, $91 \mathrm{p}$. 
16. Zhelezniak M.N. Geotemperaturnoe pole i kriolitozona iugo-vostoka Sibirskoi platformy [Geotemperature field and cryolithozone of the southeast of the Siberian platform]. Novosibirsk, Nauka, 2005, 227 p.

17. Zavadskii F.R. Dinamika formirovaniia naledei na territorii Iuzhnoi Iakutii [Dynamics of ice formation in the territory of South Yakutia]. Nauka i obrazovanie, 2013, no.2, pp.36-40.

18. Zavadskii F.R., Maksimova E.N. Monitoring podzemnykh vod $\mathrm{v}$ iuzhnoi iakutii [Monitoring of groundwater in South Yakutia]. Monitoring podzemnykh vod kriolitozony. Iakutsk, IM SO AN SSSR, 2002, pp.149-158.

19. Korzhuev S.S. Geomorfologiia doliny srednei Leny i prilegaiushchikh raionov [Geomorphology of the valley of the middle Lena and adjoining areas]. Moscow, Izdatelstvo AN SSSR, 1959, $150 \mathrm{p}$.

20. Korzhuev S.S. Merzlotnyi karst Srednego Prilenia i nekotorye osobennosti ego proiavleniia [Permafrost karst of the Middle Prienya and some features of its manifestation]. Regionalnoe karstovedenie, Moscow, Izdatelstvo AN SSSR, 1961, pp.207-220.

21. Merzlotno-landshaftnaia karta Iakutskoi ASSR [Permafrost-Landscape map of Yakutsk]. Masshtab 1: 2 500 000. Ed. P.I. Melnikov. Moscow, GUGK, 1991, 21.

22. Fedorov A.N., Botulu T.A., Varlamov S.P. et al. Merzlotnye landshafty Iakutii [Frozen landscapes of Yakutia]. Poiasnitelnaia zapiska $\mathrm{k}$ merzlotno-landshaftnoi karte Iakutskoi ASSR masshtaba 1 : 2500000. Novosibirsk, GUGK, 1989, $170 \mathrm{p}$

23. Nekrasov I.A. Kriolitozona Severo-Vostoka i iuga Sibiri i zakonomernosti ee razvitiia [Cryolithozone of the North-East and the south of Siberia and the laws of its development]. Iakutsk, Knizhnoe izdatelstvo, 1976, 248 p.

24. Nekrasov I.A., Deleur M.S., Dorofeev I.V., Gribanova S.P. Geokriologicheskoe kartirovanie Iuzhnoi Iakutii po aerokosmicheskim snimkam [Geocryological mapping of Southern Yakutia by aerospace photographs]. Regionalnye i kriolitologicheskie issledovaniia v Sibiri. Iakutsk, Institut merzlotovedeniia SO AN SSSR, 1979, pp.3-16.

25. Nekrasov I.A., Klimovskii I.V. Vechnaia merzlota zony bam [Permafrost of the BAM zone]. Novosibirsk, Nauka, 1978, 120 p.

26. Nekrasov I.A., Klimovskii I.V., Zabolotnik S.I. et al. Baikalo-Amurskaia zheleznodorozhnaia magistral. Geokriologicheskaia karta [Baikal-Amur Railway. Geocryological map]. Masshtab 1:2 5000 000. Moscow, GUGK, 1979.

27. Nekrasov I.A., Zabolotnik S.I. Geokriologicheskaia karta Amurskoi oblasti. Masshtab 2500000. Vrezka: Sezonnoe protaivanie gruntov. Masshtab 7500 000 [Geocryological map of the Amur region. Masshtab 2 500 000. Insert: Seasonal thawing of soils, Masshtab 7500 000]. Amurskaia oblast. Atlas, iss. I. Prirodnye usloviia i resursy. Irkutsk, IGSiDV SO AN SSSR, 1980, pp.49-52.
28. Nekrasov I.A., Zabolotnik S.I. Geokriologicheskie usloviia Amurskoi oblasti [Geocryological conditions of the Amur region]. Regionalnye geokriologicheskie issledovaniia v Vostochnoi Azii. Iakutsk, 1983, pp.110-124.

29. Ospennikov E.N. Dinamika geokriologicheskikh uslovii bolotnykh massivov iuga kriolitozony $\mathrm{v}$ golotsene [Dynamics of geocryological conditions of the bog masses of the south of the cryolithozone in the Holocene]. Materialy tretei konferentsii geokriologov Rossii. Moscow, Izdatelstvo Moskovskogo gosudarstvennogo universiteta 2005, pp.203-211.

30. Samsonova V.V., Kipriianova L.D. Aktivnye karstovye voronki v basseine Srednei Leny [Active karst craters in the basin of the Middle Lena]. Geograficheskie issledovaniia Iakutii: istoriia sovremennost i perspektivy: materialy vserossiiskoi nauchno-prakticheskoi konferentsii, posviashchennoi 100-letiiu so dnia sozdaniia Iakutskogo otdela Imperatorskogo Russkogo geograficheskogo obshchestva. Iakutsk, Sfera, 2014, pp.149-154.

31. Fotiev S.M. Podzemnye vody i merzlye porody Iuzhno-Iakutskogo uglenosnogo basseina [Underground waters and frozen rocks of the South Yakut coal basin]. Moscow, Nauka, 1965, $231 \mathrm{p}$.

32. Iuzhnaia Iakutiia. Merzlotno-gidrogeologicheskie i inzhenernogeologicheskie usloviia Aldanskogo gornopromyshlennogo raiona [South Yakutia. Merzlotnohydrogeological and engineering-geological conditions of the Aldan mining region]. Ed. В.А. Кудрявцев Moscow, Izdatelstvo Moskovskogo gosudarstvennogo universiteta, 1975, $444 \mathrm{p}$

33. Dalnevostochnyi gaz priberegut dlia "Sily Sibiri" [Far East gas will save for "Power of Siberia"], available at: http://gazoprovod-sila-sibiri.ru/dalnevostochnyj-gazpriberegut-dlya-sily-sibiri (accessed: 17 August 2017).

34. Shats M.M. Magistralnye gazotransportnye sistemy Sibiri (sovremennoe sostoianie i perspektivy) [Trunk gas transportation systems of Siberia (current state and prospects)]. Truboprovodnyi transport (teoriia $i$ praktika). Moscow, 2016, no.4, pp.50-57.

35. Krupneishaia sistema transportirovki gaza na vostoke Rossii [The largest gas transportation system in the east of Russia], available at: http://www.gazprom.ru. (accessed: 17 August 2017).

36. Sukhov D. Gazprom postroit do kontsa goda dve treti gazoprovoda "Sila Sibiri" [Gazprom will build two thirds of the gas pipeline "Strength of Siberia" by the end of the year"], available at: https://www.kp.ru/online/news/ 2975306/ (accessed: 17 August 2017).

37. Samsonova V.V., Druchina O.E., Samsonova M.A. Prognoznaia otsenka merzlotno-klimaticheskikh i geokriologicheskikh geotekhnicheskikh riskov stroitelstva i ekspluatatsii magistralnykh truboprovodov [Predictive estimation of permafrost-climatic and geocryological geotechnical risks of construction and operation of trunk 
pipelines]. Analiz, prognoz $i$ upravlenie prirodnymi riskami v sovremennom mire (GEORISK-2015) Materialy 9 mezhdunarodnoi nauchno-prakticheskoi konferentsii, 2015, pp.523-530.

38. Nelson F.E., Anisimov O.A., Shiklomanov N.I. Subsidence risk from thawing permafrost. Nature, 2001 (410), pp.889-890. DOI: $10.1038 / 35073746$

39. Nelson F.E., Anisimov O.A., Shiklomanov N.I. Climate change and hazard zonation inthe circum-Arctic permafrost regions. Natural Hazards, 2002, no.26 (3), pp.203-225. DOI: 10.1023/A:1015612918401

40. Sazonova T.S., Romanovsky V.E. A model for regional-scale estimation of temporal andspatial variability of active-layer thickness and mean annual ground temperatures. Permafrost and Periglacial Processes, 2003, no.14 (2), pp.125-140. DOI: 10.1002/ppp.449

41. Shur Y., Hinkel, K.M., Nelson, F.E. The transient layer: implications for geocryologyand climate-change science. Permafrost and Periglacial Processes, 2005, no.16, pp.5-17. DOI: $10.1002 /$ ppp.518

42. Anisimov O.A., Kokorev V.A., Ziltcova E.L. Temporal and spatial patterns of modern climatic warming: case study of Northern Eurasia. Climatic Change, 2013, vol.118, no.3. pp.871-883. DOI: 10.1007/s10584-013-0697-4

43. Grebenets V.I., Streletskiy D.A., Shiklomanov N.I. Geotechnical safety issues in the cities of Polar Regions.
Geography, Environment, Sustainability, 2012, no.5(3), pp.104-119. DOI: 10.24057/2071-9388-2012-5-3-104-119

44. Larsen P.H., Goldsmith S., Smith O., Wilson M.L., Strzepek K., Chinowsky P., Saylor B. Estimating future costs for Alaska public infrastructure at risk from climate change. Global Environmental Change, 2008, no.18(3), pp.442-457. DOI: 10.1016/j.gloenvcha.2008.03.005

45. Stephenson S.R., Smith L.C., Agnew J.A. Divergent long-term trajectories of human access to the Arctic. Nature Climate Change, 2011, no.1(3), pp.156-160. DOI: $10.1038 /$ nclimate 1120

46. Streletskiy D.A., Anisimov O.A. Vasiliev A.A. Permafrost degradation. Snow and Ice-Related Risks, Hazards and Disasters. Ed. W. Haeberli, C. Whiteman. Oxford, Elsevier, 2014, pp.303-344. DOI: 10.1016/B978-0-12-394849-6.00001-9

47. Streletskiy D.A., Shiklomanov N.I., Hatleberg E. Infrastructure and a Changing climate in the Russian Arctic: a geographic impact assessment. Proceedings of the 10th International Conference on Permafrost, 2012, vol.1, pp.407-412.

48. Streletskiy D.A., Shiklomanov N.I., Nelson F.E. Permafrost, infrastructure, and climate change: a GIS-based landscape approach to geotechnical modeling. Arctic, Antarctic, and Alpine Research, 2012, no.44(3), pp.368-380. DOI: $10.1657 / 1938-4246-44.3 .368$

\section{Библиографический список}

1. Алексеев В.Р. Закономерности распространения многолетне-мерзлых горных пород на юго-востоке Сибирской платформы // Геокриологические условия Забайкалья и Прибайкалья. - М.: Наука, 1967. - С. 117-123.

2. Алексеев В.Р. Индикационное значение геоботанических карт при изучении мерзлых горных пород // Докл. Ин-та географии Сибири и Дальнего Востока. 1968. - Вып. 17. - С. 20-26.

3. Алексеев В.Р. Условия формирования и распространение наледей на юге Якутии // Наледи Сибири. - М.: Наука, 1969. - С. 31-41.

4. Алексеев В.Р. Наледи как фактор долинного морфолитогенеза // Региональная геоморфология Сибири. - Иркутск, 1973. - С. 99-134.

5. Алексеев В.Р. Наледи Лено-Амурского междуречья // Сибирский географический сборник. - Новосибирск: Наука, 1975. - С. 46-127.

6. Алексеев В.Р. Принципы и методы оценки наледной опасности // География и природные ресурсы. - 1980. - №2. - С. 117-122.

7. Алексеев В.Р. Проблемы картографиирования наледных явлений // Материалы гляциологических исследований. - М., 1988. - Вып. 61. - С. 140-142.

8. Алексеев В.Р. Ландшафтная индикация наледных явлений. - Новосибирск: Наука, 2005. - 364 с.
9. Байкало-Амурская железнодорожная магистраль. Геокриологическая карта. М-б 1 : 25000 000. - М.: ГУГК, 1979. - 2 Л.

10. Балобаев В.Т. О некоторых особенностях выхода на поверхность наледных источников в Южной Якутии // Наледи Сибири. - М.: Наука. - 206 с.

11. Белокрылов И.Д., Ефимов А.И. Многолетнемерзлые породы зоны железорудных и угольных месторождений Южной Якутии. - М.: Изд-во АН СCCР $1960 .-75$ c.

12. Выпуклые бугры пучения многолетне-мерзлых торфяных массивов / Ю.К. Васильчук, А.К. Васильчук, Н.А. Буданцева, Ю.Н. Чижова. - М.: Изд-во Моск. гос. ун-та, 2008. $-560 \mathrm{c}$.

13. Геокриология СССР. Средняя Сибирь. - М.: Изд-во Моск. гос. ун-та, 1990. - 383 с.

14. Железняк М.Н. Температурное поле горных пород переходной зоны Приленского плато и ОлекмоЧарского плоскогорья // Региональные инженерные и геокриологические исследования. - Якутск: ИМ СО AH CCCP, 1985. - 117-127 c.

15. Железняк М.Н. Геотермические условия формирования и существования криолитозоны в западной части Алданской антеклизы. - Якутск: Издво СО РАН, 1998. - 91 с. 
16. Железняк М.Н. Геотемпературное поле и криолитозона юго-востока Сибирской платформы. Новосибирск: Наука, 2005. - 227 с.

17. Завадский Ф.Р. Динамика формирования наледей на территории Южной Якутии // Наука и образование - 2013. - № 2. - С. 36-40.

18. Завадский Ф.Р., Максимова Е.Н. Мониторинг подземных вод в Южной Якутии // Мониторинг подземных вод криолитозоны. - Якутск: Изд-во ИМЗ CO PAH, 2002. - C. 149-158

19. Коржуев С.С. Геоморфология долины средней Лены и прилегающих районов. - М.: Изд-во АН СССР, 1959. - 150 c

20. Коржуев С.С. Мерзлотный карст Среднего Приленья и некоторые особенности его проявления // Региональное карстоведение. - М.: Изд-во АН СССР, 1961. - C. 207-220.

21. Мерзлотно-ландшафтная карта Якутской АССР. М-б 1: 2500000 / ред. П.И. Мельников. - М.: ГУГК, 1991. - 2 л.

22. Мерзлотные ландшафты Якутии: Пояснительная записка к Мерзлотно-ландшафтной карте Якутской АССР масштаба 1 : 2500000 / А.Н. Федоров, Т.А. Ботулу, С.П. Варламов [и др.] - Новосибирск: ГУГК, 1989. - $170 \mathrm{c}$.

23. Некрасов И.А. Криолитозона северо-востока и юга Сибири и закономерности ее развития. - Якутск: Кн. изд-во, 1976. - 248 с.

24. Геокриологическое картирование Южной Якутии по аэрокосмическим снимкам / И.А. Некрасов, М.С. Делеур, И.В. Дорофеев, С.П. Грибанова // Региональные и криолитологические исследования в Сибири. - Якутск: Институт мерзлотоведения СО АН СССР, 1979. - С. 3-16.

25. Некрасов И.А., Климовский И.В. Вечная мерзлота зоны БАМ. - Новосибирск: Наука, 1978. - 120 с.

26. Байкало-Амурская железнодорожная магистраль. Геокриологическая карта. М-б 1 : 25000000 / И.А. Некрасов, И.В. Климовский, С.И. Заболотник [и др.]. - М.: ГУГК, 1979.

27. Некрасов И.А., Заболотник С.И. Геокриологическая карта Амурской области. М-б 2500000. Врезка: Сезонное протаивание грунтов, м-б 7500000 // Амурская область: атлас. - Вып І. Природные условия и ресурсы. - Иркутск: ИГСиДВ СО АН СССР, 1980. С 49-52.

28. Некрасов И.А., Заболотник С.И. Геокриологические условия Амурской области // Региональные геокриологические исследования в Восточной Азии. Якутск, 1983. - С. 110-124.

29. Оспенников Е.Н. Динамика геокриологических условий болотных массивов юга криолитозоны в голоцене // Материалы третьей конференции геокриологов России. - М.: Изд-во Моск. гос. ун-та, 2005. - C. 203-211.
30. Самсонова В.В., Киприянова Л.Д. Активные карстовые воронки в бассейне Средней Лены // Географические исследования Якутии: история, современность и перспективы: материалы Bсерос. науч.-практ. конф., посвящ. 100-летию со дня создания Якутского отдела Императорского Русского географич. общ-ва. - Якутск: Сфера, 2014. - С. 149-154.

31. Фотиев С.M. Подземные воды и мерзлые породы Южно-Якутского угленосного бассейна. - М.: Наука, 1965. - 231 с.

32. Южная Якутия. Мерзлотно-гидрогеологические и инженерно-геологические условия Алданского горнопромышленного района / под ред. В.А. Кудрявцева. - М.: Изд-во Моск. гос. ун-та, 1975. - 444 с.

33. Дальневосточный газ приберегут для «Силы Сибири» [Электронный ресурс]. - URL: http:// gazoprovod-sila-sibiri.ru/dalnevostochnyj-gaz-priberegutdlya-sily-sibiri/. (дата обращения: 17.08.2017).

34. Шац М.M. Магистральные газотранспортные системы Сибири (современное состояние и перспективы) // Трубопроводный транспорт (Теория и практика). - М., 2016. - №4. - C. 50-57.

36. Сухов Д. Газпром построит до конца года две трети газопровода «Сила Сибири» [Электронный pecypc]. - URL: https://www.kp.ru/ online/news/2975306/ (дата обращения: 26.12.2017).

37. Самсонова В.В., Дручина О.Е., Самсонова М.А. Прогнозная оценка мерзлотно-климатических и геокриологических геотехнических рисков строительства и эксплуатации магистральных трубопроводов // Анализ, прогноз и управление природными рисками в современном мире (ГЕОРИСК-2015): материалы 9-й Междунар. науч.практ. конф. - 2015. - С. 523-530.

38. Nelson F.E., Anisimov O.A., Shiklomanov N.I. Subsidence risk from thawing permafrost // Nature. 2001. - 410. - P. 889-890. DOI: 10.1038/35073746

39. Nelson F.E., Anisimov O.A., Shiklomanov N.I. Climate change and hazard zonation inthe circum-Arctic permafrost regions // Natural Hazard. - 2002. - № 26 (3). P. 203-225. DOI: 10.1023/A:1015612918401

40. Sazonova T.S., Romanovsky V.E. A model for regional-scale estimation of temporal andspatial variability of active-layer thickness and mean annual ground temperatures // Permafrost and Periglacial Processes. 2003. - № 14 (2). - C. 125-140. DOI: 10.1002/ppp.449

41. Shur Y., Hinkel K.M., Nelson F.E. The transient layer: implications for geocryologyand climate-change science // Permafrost and Periglacial Processes. - 2005. № 16. - C. 5-17. DOI: 10.1002/ppp.518

42. Anisimov O.A., Kokorev V.A., Ziltcova E.L. Temporal and spatial patterns of modern climatic warming: case study of Northern Eurasia // Climatic Change. - 2013. - Vol. 118, № 3. - P. 871-883. DOI: $10.1007 / \mathrm{s} 10584-013-0697-4$ 
43. Grebenets V.I., Streletskiy D.A., Shiklomanov N.I. Geotechnical safety issues in the cities of Polar Regions // Geography, Environment, Sustainability. 2012. - № 5(3). - P. 104-119. DOI: 10.24057/2071-9388-2012-5-3-104-119

44. Estimating future costs for Alaska public infrastructure at risk from climate change / P.H. Larsen, S. Goldsmith, O. Smith, M.L. Wilson, K. Strzepek, P. Chinowsky, B. Saylor // Global Environmental Change. - 2008. - № 18(3). - P. 442-457. DOI: 10.1016/j.gloenvcha.2008.03.005

45. Stephenson S.R., Smith L.C., Agnew J.A. Divergent long-term trajectories of human access to the Arctic // Nature Climate Change. - 2011. - № 1(3). P. 156-160. DOI: $10.1038 /$ nclimate 1120
46. Streletskiy D.A., Anisimov O.A., Vasiliev A.A. Permafrost degradation // Snow and Ice-Related Risks, Hazards and Disasters / Ed. W. Haeberli, C. Whiteman. Oxford: Elsevier, 2014. - P. 303-344. DOI: 10.1016/B978-0-12-394849-6.00001-9

47. Streletskiy D.A., Shiklomanov N.I., Hatleberg E. Infrastructure and a changing climate in the Russian Arctic: a geographic impact assessment // Proceedings of the 10th International Conference on Permafrost. - 2012. Vol. 1. - P. 407-412.

48. Streletskiy D A., Shiklomanov N.I., Nelson F.E. Permafrost, infrastructure, and climate change: a GISbased landscape approach to geotechnical modeling // Arctic, Antarctic, and Alpine Research. - 2012. - № 44(3). P. 368-380. DOI: 10.1657/1938-4246-44.3.368

Please cite this article in English as:

Zheleznyak M.N., Serikov S.I., Shatz M.M. Ecological, geocryological and geotechnical conditions of the gas transportation system "Force of Siberia". Perm Journal of Petroleum and Mining Engineering, 2018, vol.17, no.2, pp.189-200. DOI: 10.15593/2224-9923/2018.2.8

Просьба ссылаться на эту статью в русскоязычных источниках следующим образом:

Железняк М.Н., Сериков С.И., Шац М.М. Эколого-геокриологические и геотехнические условия газотранспортной системы «Сила Сибири» // Вестник Пермского национального исследовательского политехнического университета. Геология. Нефтегазовое и горное дело. - 2018. - Т.17, №2. - C.189-200. DOI: $10.15593 / 2224-9923 / 2018.2 .8$ 